\title{
AIRBORNE DOPPLER RADAR DETECTION OF LOW ALTITUDE WINDSHEAR
}

\author{
E.M. BRACALENTE, C.L. BRITT*, W.R. JONES \\ NASA LANGLEY RESEARCH CENTER, HAMPTON, VA.
} 23665

Abstract

As part of an integrated windshear program, the Federal Aviation Administration, jointly with NASA, is sponsoring a research effort to develop airborne sensor technology for the detection of low altitude windshear during aircraft take-off and landing. One sensor being considered is microwave Doppler radar operating at $\mathrm{X}$-band or above. Using a Microburst/ Clutter/Radar simulation program, a preliminary feastbllity study was conducted to assess the performance of Doppler radars for this application. Preliminary results from this study are presented. Analysis show, that using bin-to-bin AGC, clutter filtering, limited detection range, and sultable antenna tilt management, windshear from a "wet" microburst can be accurately detected 10 to $65 \mathrm{sec}$ onds (.75 to $5 \mathrm{~km}$ ) in front of the alrcraft.

Although a performance improvement can be obtained at higher frequency, the baseline $X$-band system simulated detected the presence of a windshear hazard for the "dry" microburst. Although this study indicates the feasibility of using an airborne Doppler radar to detect low altitude microburst windshear, further detafled studies --including future flight experiments -. will be required to completely characterize the capabilities and IImitations.

\section{Key Words}

Avlation safety, windshear detection and avoldance, windshear hazard index, alrborne remote sensor technology, mlcrowave Doppler radar.

\section{Nomenclature}

A/D Analog to Digital

AGG Automatic Gain Control

A/C Aircraft

c Speed of light, $\mathrm{m} / \mathrm{s}$

CSD Clutter Spectral Density

GSR Clutter-to-Signal ratio

D Rain drop diameter, mm

dB Decibels

$d B w$ Declbels relative to 1 watt

dBz Reflectivity factor in Decibels

F Hazard factor

$F_{R}$ Radial component of hazard factor

$\mathrm{g}$ Acceleration of gravity, $\mathrm{m} / \mathrm{s}^{2}$

$G$ Peak antenna gain

I\&Q In-phase and Quadrature

$k$ Boltzmann's constant, Joules/Kelvin

$k_{w}$ Refractive Index factor for rain

\footnotetext{
*Affiliation: Research Triangle Inst., Hampton, VA
}

This paper is declared a work of the U. S. Government and is not subject to copyright protection in the United States
1. One-way rain attenuation loss

$1_{r}$ Recelver bandwidth loss factor

in Natural log (to the base e)

n Total rain reflectivity per unit volume

NRCS Normalized Radar Cross Section

$P_{n} \quad$ System noise power, watts

$P_{s} \quad$ Reflected signal power, watts

$P_{t} \quad$ Peak transmitter power, watts

PRF Pulse Repetition Frequency

$\mathrm{R}_{\mathrm{g}}$ Range bin distance from $\mathrm{A} / \mathrm{C}$, m

$R_{T}$ Range to target, meters

SAR Synthet1c Aperture Radar

SCR Signal-to-Clutter ratlo

SNR Signal-to-nolse rat1o

$T_{s}$ System Nolse Temperature, deg. Relvin

Tilt Antenna angle measured from $\mathrm{A} / \mathrm{C}$ glide-slope

$v$ Alrcraft alrspeed, $\mathrm{m} / \mathrm{s}$

$v_{c} \quad$ Cell volume of rain target, $\mathrm{m}^{3}$

$w_{h}$ Vertical component of inertial wind, $m / s$

$\mathrm{w}_{\mathrm{x}}$ Horizontal component of Inertial wind, $\mathrm{m} / \mathrm{s}$

$\mathrm{z}_{\mathrm{e}} \quad$ Reflectivity factor, $\mathrm{mm}^{6} / \mathrm{m}^{3}$

$T$ Transinteter pulse duration, sec.

$\phi$ Antenna $3 \mathrm{~dB}$ beamwldth, radians

$\lambda$ Wavelength, meters

\section{Introduction}

Low altitude microburst windshear is recognlzed as a major hazard during takeoff and landing of alcraft. Mlcrobursts are relatively small, intense downdrafts which spread out in all directions upon striking the ground. When such windshear is encountered at low altitudes during landing or takeoff. the pllot has little time to react correctly to maintain safe flight (F1g. 1). In the United States during the perlod 1964 to 1985, there vere 26 major civil transport alreraft accidents and four incidents lnvolving 626 fatalities and over 200 injurles for which windshear was a direct cause or a contributing factor. As part of lts integrated windshear program, the Federal Aviation Administration (FAA) jolntiy with NASA, is sponsoring a research effort to develop alrborne sensor technology for detection of low altitude windshear during $A / C$ takeoff or landing. A primary requirement for an alrborne forward-looking sensor or system of sensors is to be capable of detecting both heavy ("wet") and light ("dry") preclpitation mferobursts. One sensor being considered for this application is microwave Doppler radar operating at $\mathrm{X}$-band or higher frequency. Since absolutely clear a Ir produces no radar return at microwave frequencles except very slight scattering from gradients in the index of refraction on the scale of the r.f. wavelength, the emphasis in the present research is on those microburst containing at least some 1lquid water. 
Previous experiments ${ }^{1}$ and studies have demonstrated, In a ilmited way, the capability of alrborne Doppler radars to detect the presence of windshear. However, for A/C landing and take-off applications, the problems of severe ground clutter. rain attenuation, and low reflectivity levels must be solved. To consider these problems, a Microburst/Clutter/Radar simulation program has been developed to ald in the evaluation and development of Doppler radar concepts. The simulation program incorporates windfleld and reflectivity databases derived from a high resolution numerical windshear mode ${ }^{2}$, clutter maps derived from a1rborne Synthetic Aperture Radar (SAR) backscatter data, and varfous airborne Doppler radar conflgurations and signal processing concepts. The program simulates the operation of a Doppler radar located in an $A / C$ approaching a runway, sensing signal returns from a vindshear microburst and an alrport clutter environment. A description of the Microburst/Clutter/Radar stmulation program is presented along with examples of simulation outputs.

Using this program, a preliminary tradeoff and assessment study was conducted to eveluate the performance of Doppler radars to detect windshear during $A / C$ landing. Case study results for a strawman design are presented, lllustrating alrborne Doppler radar capabilitles. Results for both a "wet" and "dxy" mlcroburst are included. This preliminary study shows the feasibility of using alxborne Doppler radars to detect windshear; however, further detalled studies will be required, includIng future flight experiments, to completely characterize their capabilities and limitations.

\section{Doppler Radar Desfgn Requlrements and Performance Tradeoffs}

\section{Preliminary Design Requirements}

A preliminary set of performance requirements ${ }^{3}$ has been established for design of forward-looking windshear detection sensors. The sensors' primary requirement is to detect severe mlcroburst windshear during final approach to landing (FIg. 1) or during takeoff, and to provide as a minimum, 15 to 40 seconds (approximately 1 to $3 \mathrm{~km}$ ) warning to the pllot. Advisory information on vindshear conditions 50 to 100 seconds (4 to $8 \mathrm{~km}$ ) in front of the $A / C$ is also desired. The sensor or sensor system must be able to detect windshear caused by both heavy and 1ight precipitation inlcrobursts. The sensor must measure mean hortzontal wind speeds every 150 to 300 meters out to range of 6 to $8 \mathrm{~km}$ along the flight path and a small sector (approx. $20 \mathrm{deg}$.) on elther side of the $A / C$, with epproximately $1 \mathrm{~m} / \mathrm{s}$ accuracy. These primary requirements have been established as minimum guldelines for developing sensor design requirements and evaluatIng potential concepts. The requirements to provide other information and capabilities, such as vertical vind speeds, rain reflectivity, wind turbulence, microburst signature recognition, and varlous display capabilities have not been estab11shed. Guldelines for these requirements are being developed.
A major area of radar design that requires extensive development is the radar signal processing technique, whlch will suppress clutter interference and provide maximum windshear detection accuracy. Before these techniques can be developed and evaluated, radar parameters must be chosen a evaluated. The radar parameters chosen by the radar designer are those which go in the radar equation to compute Signal-to-Nolse Ratio (SNR) performance. The SNR for a slgnal reflected from a distant rain cell target is approximated by the following equatlons: 4

$$
\begin{aligned}
\text { SNR }= & \frac{P_{s}}{P_{n}}=\frac{P_{E} G^{2} 1^{2} 1_{T} \lambda^{2} n V_{c} T}{2 \ln (2)(4 \pi)^{3} k T_{s} R_{T}{ }^{4}} \\
\text { where: } & \begin{aligned}
P_{n} & -k T_{s} / T \\
n & =10^{-18}\left(\pi^{5} / \lambda^{4}\right)\left|k_{w}\right|^{2} Z_{e} \\
& Z_{\theta}=\left(1 / \Delta V_{c} \frac{2 \sum D_{i}^{6}}{i}\right. \\
& v_{c}=(\pi / 4) R_{T} \phi^{2}(c T / 2)
\end{aligned}
\end{aligned}
$$

As seen from these equations a large number of parameters affect the performance of the radar. The deslgner, however, has control over only a few of them, malniy transmitter power, antenna gain, frequency of operation, pulse duration, and to a minor degree, target range. There 1s, for alrborne operation, a number of factors whlch limits the cholce of values for these parameters. The use of higher operating frequencles provides greater sensitivity to rain reflectivity $(3)$ and higher resolution $(5)$. but is subject to greater attenuation by rain. Most operational Doppler weather radars operate at frequencies of S-band $(1-3 \mathrm{GHz}), \mathrm{C}$-band (3-8 GHz), and $X$-band $(8-12 \mathrm{GHz})$, Although negl1glble attenuetion occurs at S-band, the increase in sensitivity and smaller cell resolution at $X$-band outwelghs the small increase in attenuation (2-5dB) experfenced for "wet" microbursts. For "dry" microbursts, frequencles in the Xu-band (12-18 $\mathrm{chz}$ ) region could be considered since attenuation would remain low. Windshear detection capability for both "wet" and "dry" microbursts could utilize dual frequency operation, but practical considerations make it desirable to find one frequency that can provide acceptable performance for all microbursts. 
Alrborne weather radars, operate in an allocated frequency band around $9.3 \mathrm{GHz}$ and ut11Lze solld state transmitters of about 100 watts. They are presently in use to display rain reflectivity and wind turbulence advisory information to the pllot. Therefore, It is of interest to assess alrborne Doppler radar concepts for windshear detection operating in this frequency band utilizing relatively low powers. Space ilmitation in the nose radome of passenger $A / C$ Limit the maximum antenna slze to about $30-36$ inches $(.76-.91 \mathrm{~m})$ In larger $A / C$ and about 18-20 inch in smaller A/C. Th1s makes it more important, from a resolution and sensitivity standpolnt, to operate at the higher frequencles. It 1s desirable to kep transmitter power requirements low so that solid state transmitters can be consldered. Other radar parameters such as pulse repetition frequency (PRF), and pulse width are chosen to minimize velocity and range foldover problems and to provide acceptable range resolution. Table 1 lists the range of radar parameter values being considered in the feaslbility study, and which represent state-of-the-art alrborne Doppler radar hardware implementacion capabllity. Also listed is a baseline set of values used in the inftial radar simulation case studies.

Table 1 Wind shear Doppler radar parameter values

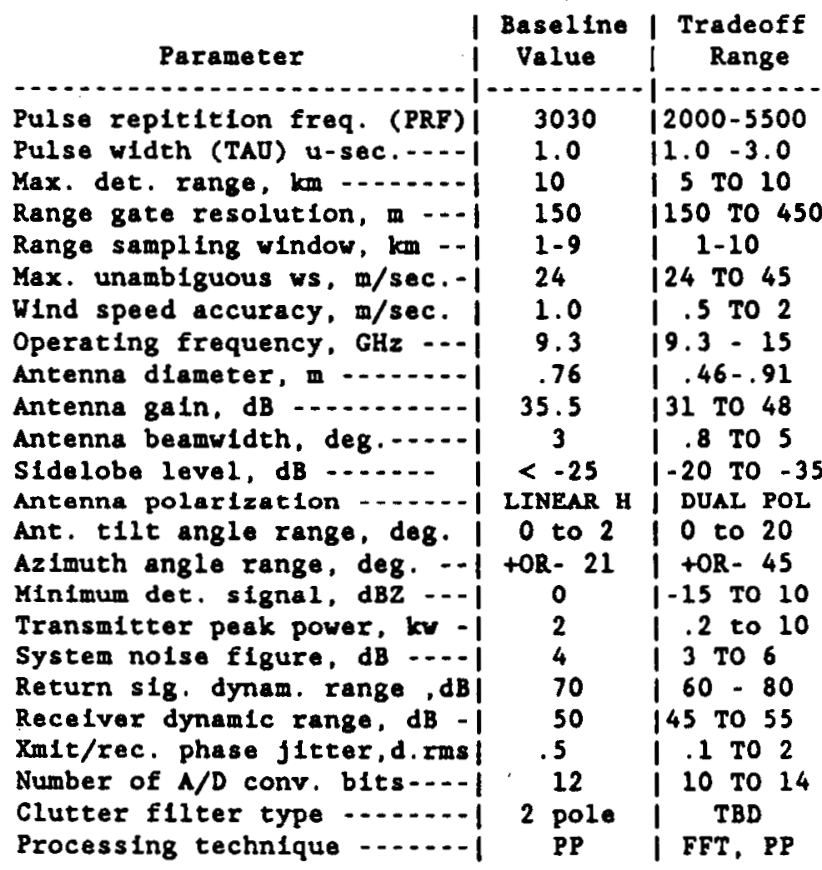

SNR Performance

Using selected values of parameters found in table 1, a set of SNR performance curves were computed using (1). Sample plots of these SNR curves are shown in figures $2 \& 3$. The SNR is computed in a bandwidth equal to $1 / T$. A SNR in this bandwidth of greater than unity $(O \mathrm{~dB})$ is generally required to obtain adequate Doppler processing performance. These curves show that SNR performance exceeding 0 $\mathrm{dB}$ can be obtained for relatively low reflectivity levels ( 0 to $10 \mathrm{dBz}$ ) for ranges out to $10 \mathrm{~km}$. Reflectivity values range from $60 \mathrm{dBz}$ in the core of "wet" m1crobursts, to 10 to $40 \mathrm{dBz}$ in the outflow region. The performance curves for both the $9.3 \mathrm{GHz}$ ( $f 1 \mathrm{~g} .2$ ) and $15 \mathrm{GHz}$ ( $f 1 \mathrm{~g} .3$ ) show more than sufficlent SNR performance for these ranges of reflectivities. For "dry" microbursts the core reflectivity can be in the range of 20 to $30 \mathrm{dBz}$ range, falling to -20 to $+5 \mathrm{dBz}$ in the outflow region. The 9.3 and $15 \mathrm{GHz}$ performance for a -10 $\mathrm{dBz}$ reflectivity falls below $0 \mathrm{~dB}$ SNR at about $3 \mathrm{~km}$ and $6 \mathrm{~km}$ respectively, which are still acceptable ranges for this application. An increase in transmitter power would be required to operate down to the $-20 \mathrm{dBz}$ level.

\section{Clutter Performance}

The $X$ and Ku-band SNR performance was shown in the previous section to be more than sufficient to allow adequate Doppler processing. However, one of the major problems associated with the sensing of microburst using an alrborne Doppler radar is the presence of ground clutter. To assess the magnitude of this problem, an analysis of clutter spectra and clutter-to-signal (CSR) ratios was conducted, using ground clutter maps derived from we11-callibrated SAR Normalized Radar Cross Section (NRCS) data as described in section III. A set of clutter maps has been produced for a number of different airports from existing sets of SAR data. Figures $4 \& 5$ show sample clutter-to-signal (CSR) ratio results, assuming a $10 \mathrm{dBz}$ rain reflectivity signal level, for a few sample radar configurations approaching Willow Run afrport. Plots are shown for a $5 \mathrm{~km} \mathrm{~A} / \mathrm{C}$ range from touchdown, antenna t1lt angles of $0^{\circ}$ and $2^{\circ}$ (antenna angle measured up from the $A / C$ glide-slope of $-3^{\circ}$ ), and antenna azimuth angles of $0^{\circ}$ and $10^{\circ}$. Table 2 lists the radar parameters used in these analyses. Figure 6 shows a histogram plot of the range of NRCS levels which exist in the clutter map used. The NRCS levels larger than -10 dB come primarily from urban areas and high level discrete targets.

Table 2 Radar parameters used in clucter analys1s

$A / C$ range from runway - - $5 \& 7 \mathrm{~km}$

$A / C$ ground velocity -... $77 \mathrm{~m} / \mathrm{s}$

A/C glide slope ........ $3^{\circ}$

Frequency …......... $9.3 \mathrm{GHz}$

Antenna Dia. -.......

Antenna edge $111 \mathrm{um} . \cdots-10 \mathrm{~dB}$

Rain Reflectivity -.... $10 \mathrm{dBz}$

Pulse width ......... I u-sec.

PRf .............. 5000

Ant. t1lt angle ....... $0 \& 2$ deg.

Ant. azfmuth angle .... 0 \& $10 \mathrm{deg}$. 
The results of this preliminary clutter analysis shor that the highest clutter levels (CSR of 30-60 dB) occur where the pulse in the main beam intersects the ground, from the urban areas, and for antenna tilt angle of $0^{\circ}$. Two significant results are shown by these analyses, which can be ut11lzed to greatly reduce the effects of clutter. First, lower CSR values occur at short ranges in front of the $A / C$, at range gates where the pulse in the main beam has not touched the ground. At these ranges the cluter is coming primarily from sidelobes, which if sufficiently low will suppress the clutter signals. For a $3^{\circ}$ beamwidth antenna polnted down at a $0^{\circ}$ tilt angle and $5 \mathrm{~km} A / C$ range, the $-3 \mathrm{~dB}$ polnt of the main beam first touches the ground at about $3.5 \mathrm{~km}$, and the first sidelobe null polnt at about $2.7 \mathrm{~km}$ (a polnt about 35 seconds ahead of the alrcraft). For a $2^{\circ}$ t11t these points are about 6 and $4.3 \mathrm{~km}$ respectively. Note in figure 4 the increase in CSR at a range of $2.5 \mathrm{~km}$. Th $1 \mathrm{~s}$ point corresponds to NRCS levels of -5 to $0 \mathrm{~dB}$ from a residentlal area about 2.5 to $3 \mathrm{~km}$ from the runway. The clutter level would have been much hlgher had the main beam been viewing this area rather than the beam sidelobes.

A second fact that is very evident in the data is the significant reduction in clutter that occurs when the antenna is tilted up from $0^{\circ}$ to $2^{\circ}$. Thus, by $11 m i t$ ing the range of data procesaing and employing proper antenna tilt control, CSR levels can be kept below $40 \mathrm{~dB}$ (vell within the dynamic range capabilities of present day Doppler radar recelver design technology). Clutter suppression techniques can then be employed to reduce clutter to acceptable levels. Figure 7 shows a sample clutter spectral density plot for the $2.5 \mathrm{~km}$ range gates of figure 4 (ant. Tilt $-2^{\circ}, A z=0^{\circ}, A / C$ at 5 $\mathrm{km})$. The density levels are plotted against veloclty relative to the $A / C^{\prime} s$ ground velocity. With the most signiflcant clutter spectrum energy levels contalned between zero and about $4 \mathrm{~m} / \mathrm{s}$, a high pass filter with maximum attenuation at zero velocity can be employed to significantiy reduce the clutter levels. The CSR shown In f1gure 7 w111 be reduced by over $25 \mathrm{~dB}$ if the energy below $3 \mathrm{~m} / \mathrm{s}$ is filtered out. Since the most severe wind velocities of interest exlst at much higher speeds $(5-30 \mathrm{~m} / \mathrm{s})$, this filter will have little effect on the wind speed velocity estimation. Studies are underway to evaluate filter processing techniques which can provide optimum results. Section IV presents sample case study results of windshear detection performance, using the radar simulation program.

\section{RADAR SIMULATION}

\section{General Description}

The radar simulation program is a comprehensive calculation of the expected output of an airborne coherent pulsed Doppler radar system viewing a lowlevel microburst along or near the approach path of the alrcraft. Flgure 8 is a block diagram showing the major features of the simulation. Iriputs the program Include the radar system paraideters an.. large data files that contain the characteristics of the ground clutter and the microburst. The ground clutter data file consists of high-resolution (20m) calibrated synthetic Aperture Radar (SAR) data of selected alrport areas. The microburst data files provide reflectivity factors, $x, y, z$ wind velocity components, and other meteorological parameters with a resolution of 40 meters. This database is generated by a numerical convective cloud mode $2^{2}$ driven by experimentally-determined initial conditions, and represents selected time perlods of the microburst development.

For each range bin, the simulation calculates the recelved signal amplitude level by integrating the product of the antenna gain pattern and scattering source amplitude and phase over sphericalshell volume segment defined by the pulse width, radar range and ground plane intersection. The amplitude of the return from each incremental scatterer in the volume segment is proportional to elther the square root of the normalized cross-section of the ground clutter (from the clutter map) or the square root of the reflectivity factor of the water droplets in the microburst (from the microburst data base). The phase of each incremental scatterer-4s the sum of aniformly distributed $(0-2 \pi)$ random phase term, a phase term due to relative alrcraft-scatterer radial velocity, and normally-distributed random phase terms representIng transmitter/recelver phase jltter and ground clutter random motion. The random phase terms simulating phase jltter and ground clutter motion are updated for each transmitted pulse, while the uniformly-distributed phase terms are updated for each sequence of pulses in range bin. The phase terms representing ircraft-scatterer relative motion are linear functions of time.

Path attenuation for each incremental scatterer is determined by integrating the path losses over the transmission path. Emplrical formulas ${ }^{4}$ are p'sed to determine the incremental path losses from the liquid water content of the microburst. Aircraft ground velocity is assumed to be known accurately so that derived Doppler frequencles can be referenced to a value of zero corresponding to that velocity.

Antenna patterns simulated include a generic parabolic antenna with size and aperture lliumination taper specified by input data, and a flatplate array antenna with pattern simllar to that found in the current generation of $X$-band afrborne weather radars. 
In the simulation, a sequence of $N$ pulses of inphase (I) and quadrature (Q) signal amplitudes are calculated for each range bin as discussed above and subjected to AGC amplification and $A / D$ quant 1 zation. A simulated fast-acting AGC la used to adjust the gain of the system on a bin-by-bin basis to achleve a wide dynamlc range and to prevent s1gnal saturation (due to clutter) prlor to and durling $A / D$ conversion. The $I$ and $Q$ pulse stream is then digltally flltered to suppress ground clutter near zero Doppler frequencles and processed using both conventional pulse-palr and spectral averaging algorlthms to derive the average velocity and spectral width of the scatterers in the range bin. Further processing of the velocity data provides Information on indshear and alrcraft hazard factor.

Provision is made in the simulation to generate returns from a specifled number of range bins over a specified azimuth scan so that simulated color displays of reflectivity, velocity, windshear, spectral width, etc., can be examined. other outputs of the simulation include plots of power levels, velocity, spectral width, windshear hazard factor, and AGC levels vs, radar range. Doppler spectra of ground clutter and molsture as derlved from the $I$ and $Q$ signals from each simulated range bin are also plotted.

\section{M1croburst Mode1}

As mentioned above, the microburst model is a detalled numerical convective cloud and storm model that calculates the time history of the development of a mlcroburst. The model uses nonhydrostatic, compresstble and unsteady set of governing equatlons which are solved on a three-dimenslonal staggered grid. The computation can be initlated from observed data and generates realistic wind flelds that compare favorably with observed data such as that obtained in the JAWS study ${ }^{5}$. For the radar simulations to date, a $4 \times 4 \mathrm{~km}$ lattice of $40 \times 40$ meter grid spacing increments (two-dimensional axisymmetric version) has been generated at selected time periods. Output parameters include the radar reflectivity factor ( $\mathrm{dBz}$ ), wind velocity components, temperature, equivalent potential temperature, pressure and molsture content (water vapor, 1ce, cloud droplets, rain, snow and hall/graupel). The model developed under NASA aponsorship is described in detall in references 2 and 5 .

For the radar simulation cases discussed in this paper, a typical "wet" microburst and a typlcal "dry" microburst were selected and used to lnvest1gate radar performance at a particular instant of time. Flgure 9 shows the reflectivity factors and velocity fleld of the axisymetric "ret" microburst used In the radar simulation. The "dry" microburst is simllar in form but with smaller dimensions, lower wind speeds, and much lower reflectivity leve1s. The "wet" microburst data are taken at 11 minutes after inftiation of the microburst calculatIon and the "dry" mlcroburst data are 23 minutes after inftiation. The "wet" microburst resembles an axisymmetrlc version of the 2 August, 1985, Dallas-Ft. Worth storm 6 and the "dry" microburst is based on soundings taken on $14 \mathrm{Julg}, 1982$, within the JAWS network near Denver.

\section{Clutter Mode1}

The ground clutter model used for the present simulation cases is a high-resolution X-band SAR map of the Wlllow Run, Mlchlgan, alrport area pro$v$ ided by the Environmental Research Institute of MIchIgan (ERIM).

The SAR Image flles produced by ERIM provide callbrated NRCS data with a resolution of $20 \mathrm{~m}$. Flgure 10 shows a high resolution (3m) SAR image of Willow Run alrport from which this data was derlved and the runway ( $9 R$ ) used in the simulation runs. In the simulations, the alrcraft is positioned at a selected distance from the runway touchdown point on a three-degree glide slope.

A problem with the use of existing SAR data is assoclated with the vatiation of cross section with depression angle. These data were taken at depression angles ranging from approximately 18 to 50 degrees, whereas for the operational alrborne radar simulated the depression angles of interest are approximately 1 to 20 degrees. To partlally account for this difference, ERIM supplied an emplrtcal depression-angle correction function that corrects the NRCS to the angle seen by the alrborne radar. Since clutter sources from urban areas have cross sections that do not decrease ignificantly wth depression angles in the ranges of interest. urban areas of the clutter map are excluded from this depression angle correction and the or 1 ginally measured cross-section values are used in the simu. lation. Also, areas of the map vith NRCS values equal to or greater than $5 \mathrm{~dB}$ are not corrected.

The corrections for depression angle are not entirely satisfactory, and cause an uncertainty in the clutter calculations of the preliminary cases discussed in this paper. Flight experiments using the ERIM SAR Instrument w111 be flown in the summer and fall of 1988 to collect more representative alrport clutter data with depression angles corresponding to those that would be seen by an alrborne radar on the approach path. These data will provide better Information of depression angle varlation of NRCS for urban environments as well as other surfaces. 
"Wet" M1croburst

To examine the expected radar performance in specific situations, several cases have been simulated, as fllustrated in figure 1 , using the baseine system parameters given in table 1 and the ground clutter map from the Villow Run alrport area. Flgure 11 plots the SNR and SCR vs. radar range for "wet" microburst that would be seen by the radar at a distance of $7 \mathrm{~km}$ from the runway touchdown point with the antenna tilted up 2 deg from the profected alrcraft path. The microburst axis is located on the projected path $2 \mathrm{~km}$ from the touchdown point. The calculated reflectivity factor of the water droplets along a line correspondIng to the profected alrcraft path is also plotted in figure 11 for comparison to the simulated radar measurements. For this case, the SNR and SCR are hlgh over the entlre region of the microburst, with - minimum value of SCR (10dB) occurring at approximately $3 \mathrm{~km}$ from touchdown. This minlmum value is due to hlgh clutter pover from an urban ares at this location. The SNR exceeds $20 \mathrm{~dB}$ over the range, with approximately $18 \mathrm{~dB}$ difference between the near side and far side of the microburst due to path attenuation and geometrical factors (in this plot, the power levels are not corrected for the $\mathrm{R}_{\mathrm{T}}^{2}$ loss).

Figure 12 shows the calculation of the radial component of wind velocity derived from both pulsepalr and spectral averaging algorithms operating on 128 simulated $I$ and $Q$ pulses from the radar. This flgure also plots, for comparison, the "true" wind speed, deflned as the velocity component along the center line of the antenna beam. It should be noted that the true velocity, as defined, will always differ somewhat from the radar-measured velocity because the true velocity is measured along a line (the antenna center line). whereas the radar system measures a welghted (by reflectivity and antenna pattern) average of the velocity over a finite volume of the microburst.

A two-pole high-pass Butterworth fllter was used to fllter the $I$ and $Q$ pulses to suppress ground clutter. The $6 \mathrm{~dB}$ frequency response cutoff point is located at a Doppler frequency--relative to the $A / C$ ground velocity-- corresponding to a radis component of wind velocity of $3 \mathrm{~m} / \mathrm{s}$, and the filter has two zeros at zero Doppler frequency. The effect of the cluter fliter can be seen in flgure 13. which is a plot of the Doppler spectrum in a range bin $4 \mathrm{~km}$ from the radar calculated with and without the clutter filter. For simulated velocity measurements, processing threshold of $4 \mathrm{~dB}$ is used (1.e., the pulse-palr and spectral averaged veloclties are set to zero if the radar recelved power 13 less than $4 \mathrm{~dB}$ greater than the nolse threshold).
The simulated velocity measurements are within 2 $\mathrm{m} / \mathrm{s}$ of the "true" velocity for velocitles greater than $5 \mathrm{~m} / \mathrm{s}$ and indicate clearly the potentlally hazardous windshear associated with the microburst. To more closely indicate the windshear hazard to the alrcraft, measure called the F-factor or hazard index has been defined by Bowles. ${ }^{3}$ This Index is defined by the equation:

$$
F=\frac{\dot{w}_{x}}{g}-\frac{w_{h}}{v}
$$

where $W_{x}$ is the rate of change of the component of wind velocity along the alrcraft path, 8 is the acceleration of gravity. Wh is the vertical component of wind velocity and $v$ is the oircraft velocity. Values of $F$ greater than 0.1 to 0.15 ara considered hazardous to jet transport alrcraft, considering alrcraft type, configuration, and range of gross weights. ${ }^{3}$

Although a forward-looking radar sensor cannot directly measure the vertical wind component, the radial velocity component is measured directly. The first term in the equation for the $F$-factor can be derlved from radar measurements of radisl veloclty as follows:

$$
\begin{aligned}
& \text { Let } \dot{w}_{x}=v \frac{\delta W_{x}}{\delta R_{g}} \\
& \text { then } \\
& F_{R}=\frac{v}{g} \frac{\delta H_{x}}{\delta R_{g}}
\end{aligned}
$$

where:

$\delta w_{x}$ - change in radial velocity between adjacent range bins

$\delta R_{g}$ - distance between range bins

$F_{R}$ - the radial component of the hazard index

This radial term is calculated in the simulation from the velocity measurements as shown in figure 12 by averaging velocity differences over 5 range bins, and results in outputs as shown in figure 14. The radial term of the hazard factor reaches maximum value of 0.1 for this microburst, and both pulse-palr and spectral averaging algorlthms give good measurements of the factor. 
"Dry" Microburst

Simulation runs similar to those discussed above were also made with the "dry" microburst discussed previously. Figure 15. shows the hazard index derived by these runs using the baseline system parameters operating at $9.3 \mathrm{GHz}$. The figure ind cates that although the windshear was detected, the velocity measurement with the baseline set of system parameters was somewhat nolsy.

To Improve the performance on the "dry" mlcroburst, several system parameters can be changed. These trade-off studies have just been inftiated. For example, to lllustrate the radar performance at Ku-band, the dry microburst case discussed above was simulated using the same set of baseline parameters, except the operating frequency was changed to $15 \mathrm{GKz}$ and the PRF was changed to 4878 pulses per second. Results for the Ku-band system with the dry microburst are shown in flgures 16,17 , and 18 . As may be seen, even though the SNR and SCR values are much lower than those with the wet microburst. the wind velocity was successfully measured over the hazardous part of the microburst. The hazard factor calculation clearly indicates the windshear hazard assoclated with this microburst.

Stmulated DIsplays

The radar simulation program provides for an azimuth scan mode and the generation of simulated displays of several variables of interest. Figure 19 shows a black and white copy of a simulated (color) display of radial wind velocity for the "wet" mfcroburst with the baseline set of radar parameters. Figure $20 \mathrm{is}$ a simulated plot of the radial torm of the F-factor and clearly indicates that potential windshear hazard lies on the alrcraft path. These displays should not be interpreted as recommended displays for the alrcrew, since the specific method of alerting the crew to a hazard requires extensive study, which is presently under way, and will most likely consist of a warnIng light or alarm which may be supplemented by displays of additional information to ald the alrcrew's decision-making process.

\section{Euture Simulation Development}

The simulation program will be improved in the near future by incorporating more soph1sticated slgnal processing techniques, models to represent moving ground clutter, and techniques for estimat. Ing true, nuisance, and missed hazard alarms. Considerable effort is planned to incorporate and Investlgate a full range of microburst/clutter environments, provide improved displays of simulaton output data for evaluating performance, and to conduct extensive tradeoff and optimization studies.

\section{v. Concluding Remarks}

A preliminary tradeoff and assessment study was conducted to evaluate the performance of alrborne Doppler radar sensors to detect hazardous microburst windshear during $\mathrm{A} / \mathrm{C}$ landing. Using prell. minary set of performance requirements for the design of forward-looking sensors, a baseline set of radar parameters was developed for use in assessing windshear detection performance using a radar simulation program. A description was given of the simulation program, which includes excellent models of microburst wind flelds, realistic clutter maps of alrports, and accurate models of Doppler radar operation and signal processing.

For the baseline Doppler radar sensor configurations modeled, preliminary analyses of the computer simulation case studies show that windshear can be accurately detected 10 to 65 seconds in front of the alrcraft approaching a hazardous microburst positioned in the flight path of landing afrcraft. This was accomplished using a bin-to-bin AGC, clutter filterling, limited detection range, and sultable tilt management. The sensor is highly effective for the "wet" microburst where very high SNR and SCR are obtainable due to large reflectivity levels. For the "dry" microburst, with low reflectivity levels, windshear was detected, however. more tradeoff analyses and signal processing studies are needed before the performance for the "dry" microburst case can be fully assessed.

Initial simulations were conducted with a speciflc alrport, selected microburst time instants, and the baseline radar parameters. These simulations clearly show that in realistic situations, downward-looking afrborne radar sensors have the potentlal to detect windshear and provide information to the alrcrew that will permit escape or avoldance of hazardous shear situations. Plans are underway to investigate a full range of microburst/clutter environments, conduct extenslve tradeoff and optimization studies, and investigate varlous signal processing and clutter filtering concepts which can provide rellable windshear detection capabllity.

The inftial simulation studies were confined to the landing approach, since it presents the most severe slgnal-to-clutter situation. Studies of the takeoff case axe planned. Since the antenna can be t1lted up, therefore providing high signal-toclutter ratlos, acceptable detection performance is anticlpated for this case. 
Although hazardous windshear can be detected by Doppler radar, the pllot must be alerted in a timely manner to avold the hazard. A hazard index has been developed ${ }^{3}$ which establishes when a threat to the performance of the A/C exists. The simulatIon studies showed that a Doppler radar sensor can detect the horlzontal component of this index with sufficlent accuracy to indicate in a timely manner that a threat exists. Further studies using this Index will be conducted for varlous microburst types and Locations relative to the $A / C$ to assess the missed and nulsance alarm rate. Displays of additional advisory Information for the alrcrew - 111 probably be required, and are under study. output display examples from the simulation studies represent scre of the Information that could be provided.

The present and future simulation studles w111 provide a good foundation to determine the capab11. Itles and limitations of Doppler radar concepts for the detection of microburst windshear. Flight experiments are needed to evaluate the simulation modeling and performance estimates. A flight experiment program is planned for the 1990-91 time perlod. The first phase of flights will involve measuring the clutter environment from selected airports during landing approaches. These data vill be used to evaluate the clutter map models derived from the SAR data. A second phase of flights will collect data from severe convectlve storms at alt tudes above 2000 feet. These data w111 be combined with the clutter data to be used to evaluate the performance of various signal processing concepts. Flight tests for candidate concept evaluation and demonstration would follow.

\section{References}

1. Staton, L. D.: "Alrborne Doppler Radar For Wind Shear Detection," In workshop proceedings, "Wlndshear/Turbulence Inputs to F11ght Simulation 8 Systems Certiflcation." MASA CP 2474 , July 1987

2. Proctor, F. H.: "The Terminal Area Simulation System Vol. I: Theoretical Formulation." NASA CR 4046: DOT/FAA/PM-86/50, I. Apr11 1987

3. Bowles, R. L.; and Targ, R.: "windshear Detection and Avoldance: Alrborne Systems Perspect1ve." Presented at 16th Congress of the ICAS Aug 28-Sept 2, 1988, Jerusalem, Israel.

4. Dovlak, R. J.; and Zmic, D. S.: "Doppler Radar and Weather Observations." Academic Press Inc. 1984 .

5. Proctor, F. H.: "The Terminal Area simulation System Vol. II: Veriflcation Cases." NASA CR 4047: DOT/FAA/PM-86/50, II. Apr11 1987

6. Bowles, R. L.; "Windshear Kodeling: DFW Case Study", presented at conference "VIndshear Detection Forward-Looking Sensor Technology". NASA CP 10004: DOT/PAA/PS-87/2, Oct. 1987

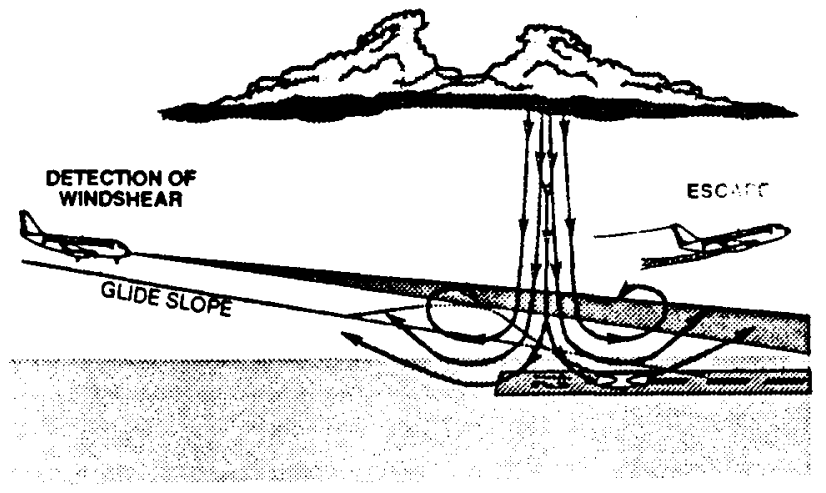

F1g. 1 sketch 11lustrating the microburst windshear hazard for an approaching $A / C$, being probed by a radar beam. Potential impact path is shown if escape or avoldance maneuver is not activated.

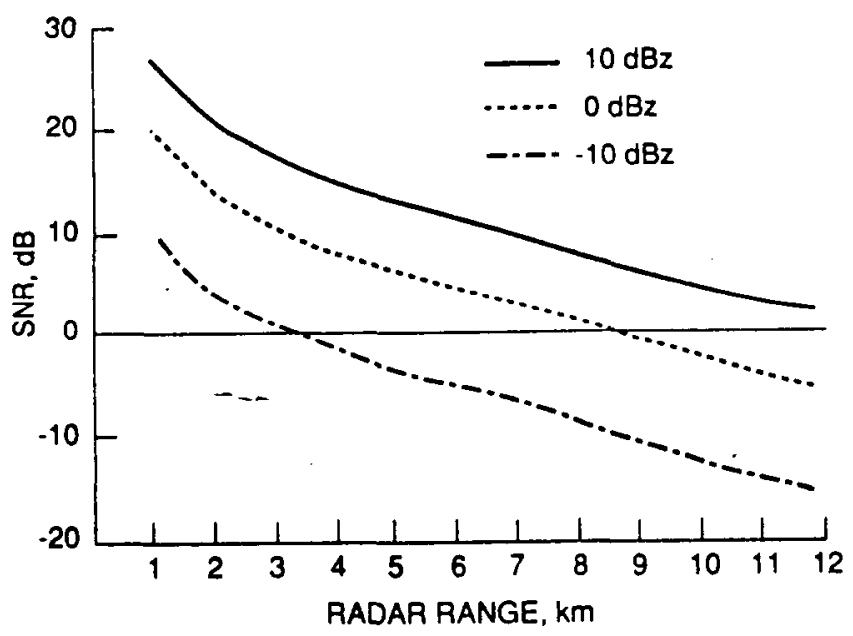

F1g. 2 Signal-to-Nolse performance for different reflectivity levels, A/C $10 \mathrm{~km}$ from touchdown, $9.3 \mathrm{GHz}, P_{\mathrm{T}}=2 \mathrm{kw}, T=1$ us, Ant. D $1 \mathrm{a} .=30$ in., T11t $=0^{\circ}$

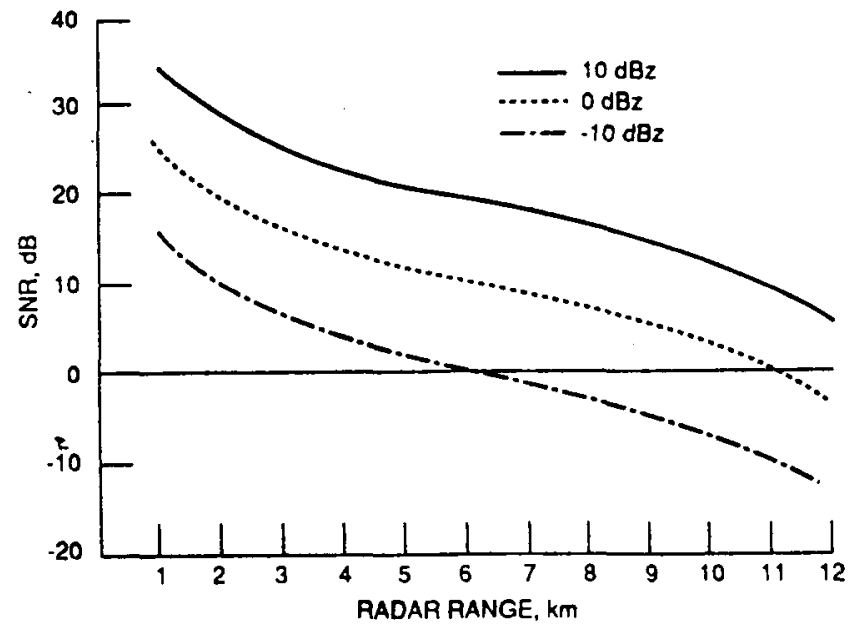

F1g. 3 Signal-to-Nolse performance for for $15 \mathrm{GHz}$. All other conditions the same as in FIg. 2 . 


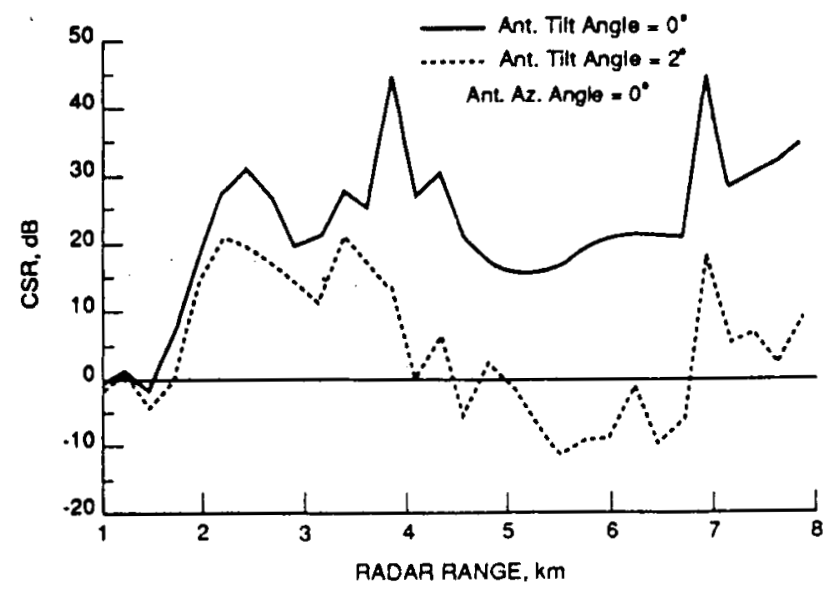

Fig. 4 Clutter-to-Signal (CSR) vs range from $M / C$. using Willow Run clutter map. $A / C 5 \mathrm{~km}$ from touchdown, Ant. Az angle $-0^{\circ}, z_{e}-10 \mathrm{dBz}$. See table 2 for other parameter values.

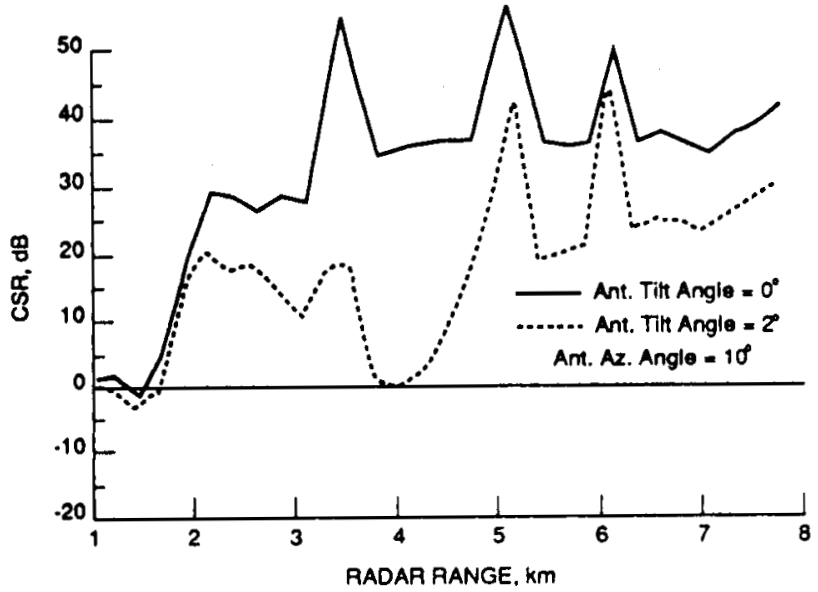

Fig. 5 Clutter-to-Signal (CSR) vs range from $A / C$ for same conditions as fig. 4 except Ant. $\mathrm{Az}$ angle $-10^{\circ}$

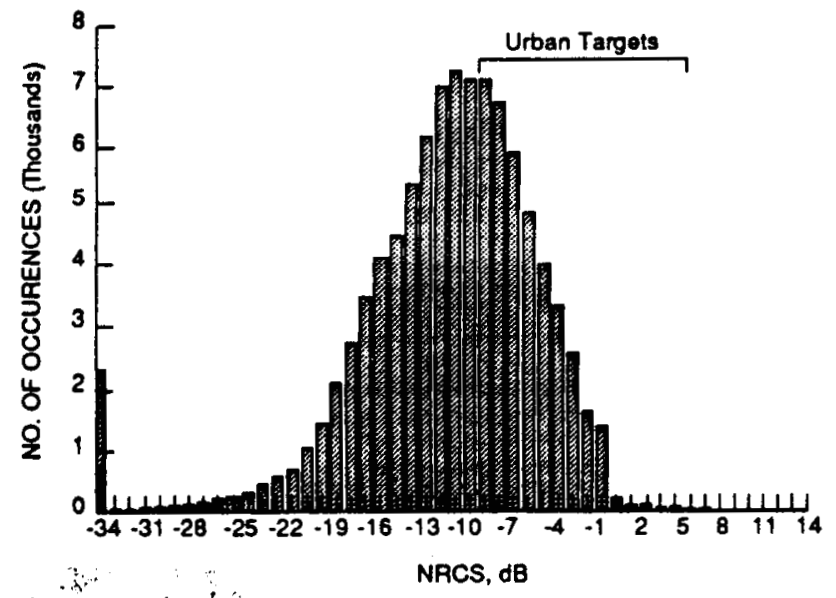

Fig. 6 :Hlstogram plot of range of NRCS levels contalned in the Wlllow Run Alrport clutter map.

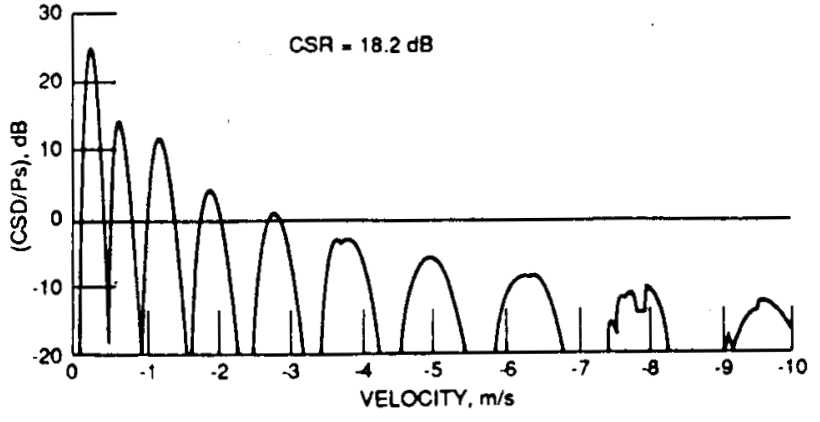

Fig. 7 Normalized clutter spectral density plot for $2.5 \mathrm{~km}$ rauge bin. A/G $5 \mathrm{~km}$ from touchdown, Ant. TIlt $=2^{\circ}, A z=0^{\circ}, z_{e}=10 \mathrm{dBz}$

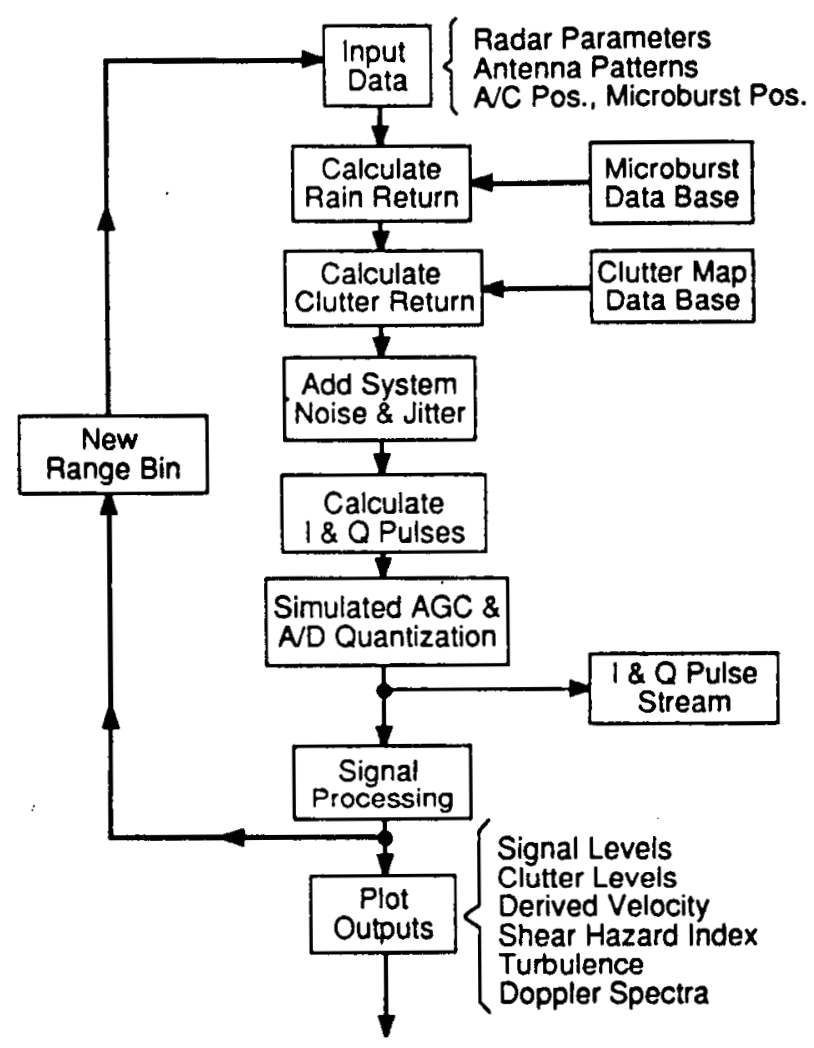

F18. 8 Block diagram of the radar simulation program showing the major features of the simulation. 


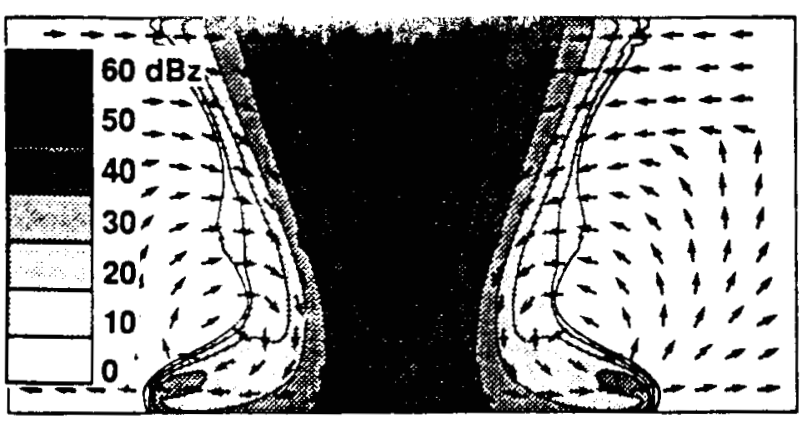

Fig. 9 Reflectivity contours and velocity fleld for the axis:metric "wet" microburst model used for inftial radar performance slmulations studies.

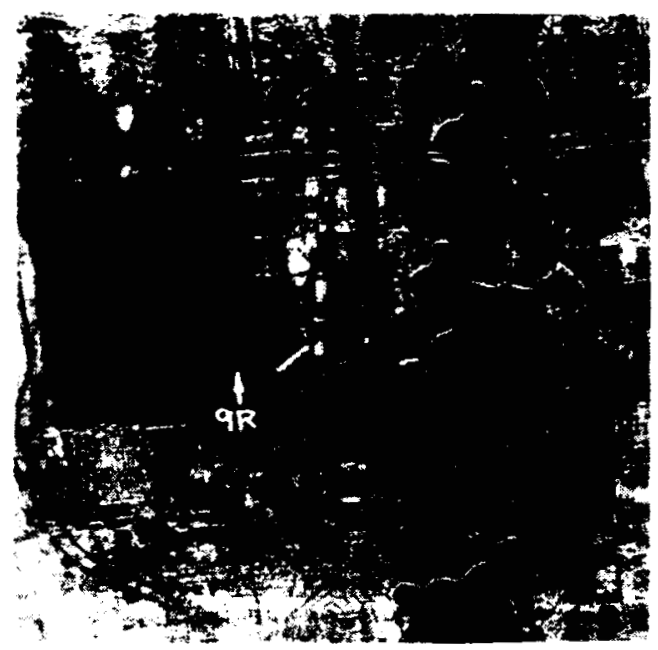

Fig. $10 \mathrm{H}$ igh resolution SAR fmage of the Willow Run, MI alrpoit area. NRCS map, produced from this image data base, is used to calculate the ground clutter return in the radar simulation program.

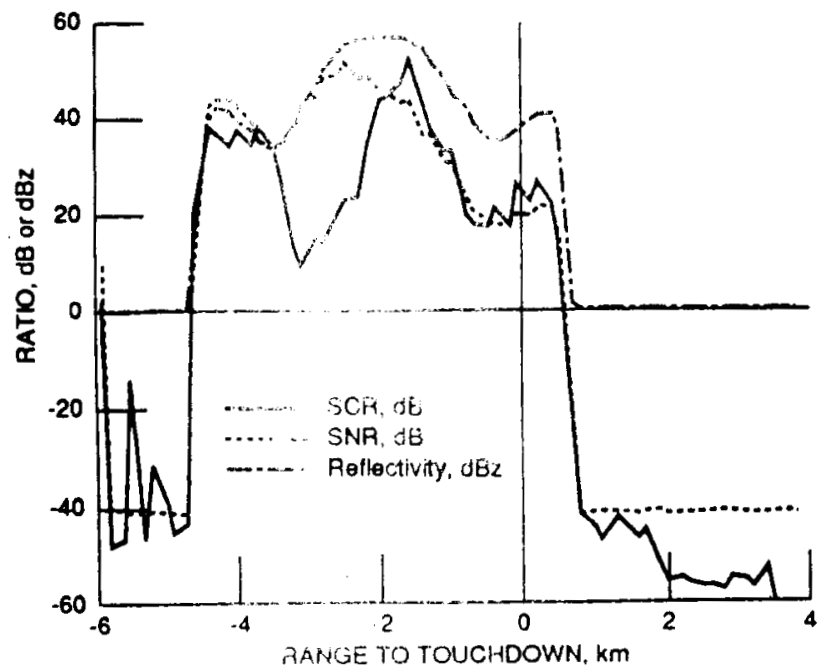

71g. Il Plot of calculated SNR, SCR and reflect1vity factor vs range to touchdown for the "wet" microburst. Alrcraft located $-7 \mathrm{~km}$ from touchdown on $3^{\circ}$ glide slope, radar antenna tilt $=2^{\circ}$, microburst centered on projected flight path $-2 \mathrm{~km}$ from the touchdown polnt, freq. $=9.3 \mathrm{GHz}$.

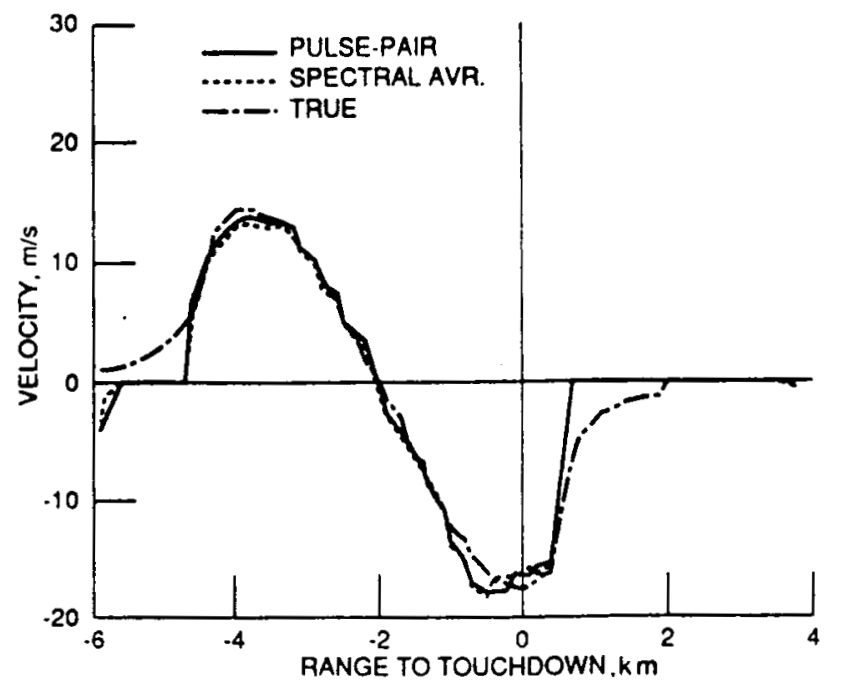

F1g. 12 Radar wind veloclty measurement vs range to touchdown; same conditions as in figure 11. In this plot, positive velocities represent headwinds.

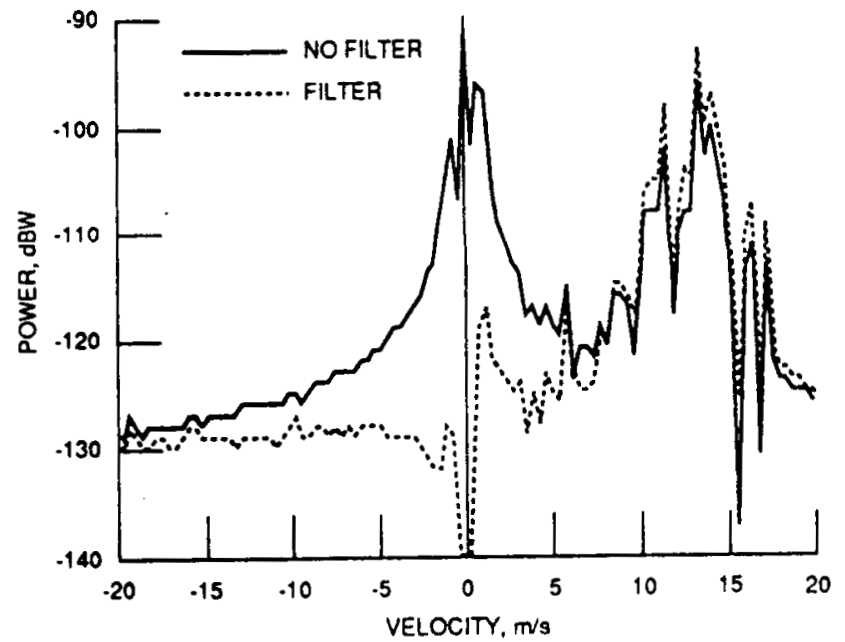

Fig. 13 Plot of Doppler spectrum from radar range bin $4 \mathrm{~km}$ from touchdown, prior to wind velocity estimation, showing effect of 2-pole filter used to suppress ground cluter.

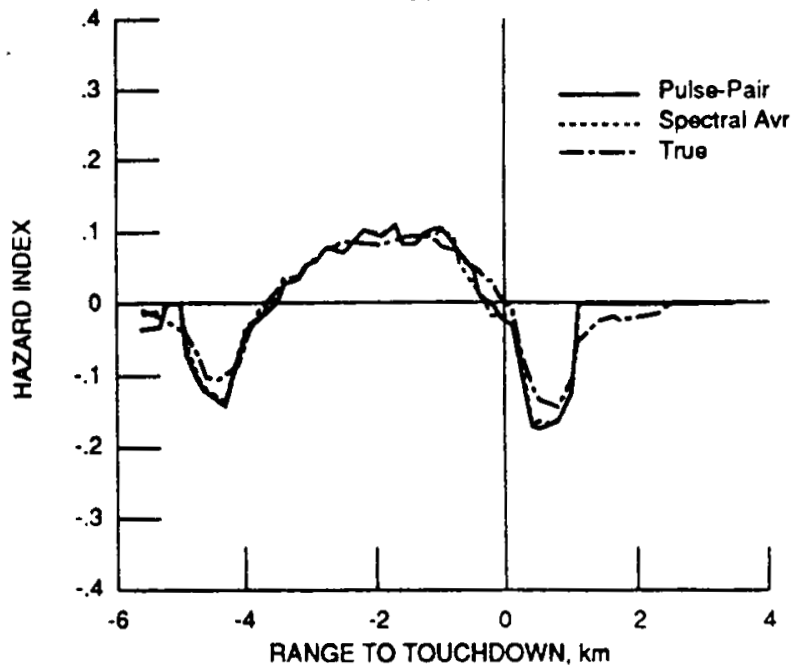

F1g. 14 Hazard index vs. range to touchdown derived from the velocitles shown in figure 12 Index is calculated from average velocity differences over 5 range cells ( $750 \mathrm{~m}$ ). 


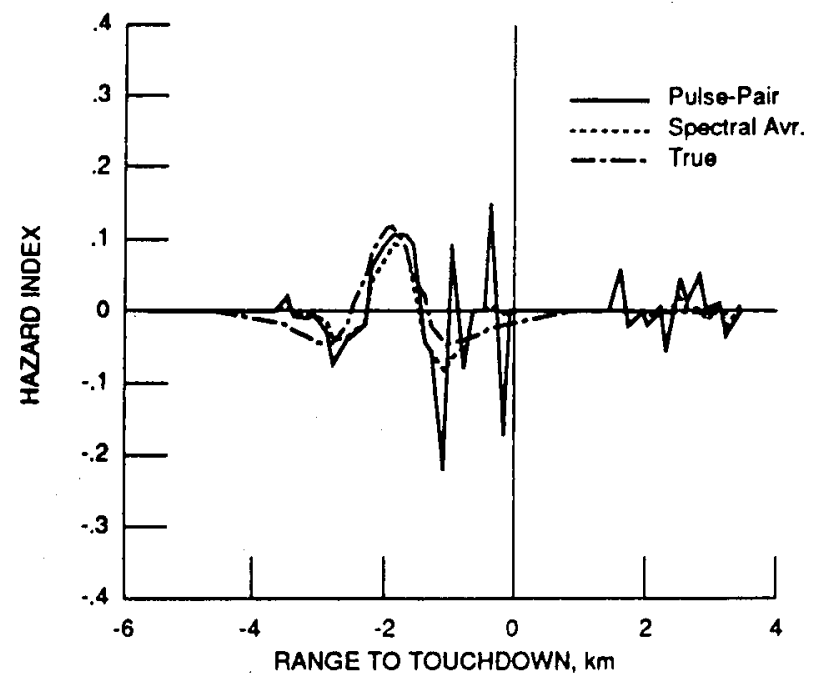

Fig. 15 Hazard Index vs. range to touchdown derlved from the "dry" microburst volocities using the baseline parameters, and conditions 11sted in $\mathrm{flg}$. 11 , freq. $-9.3 \mathrm{GKz}$.

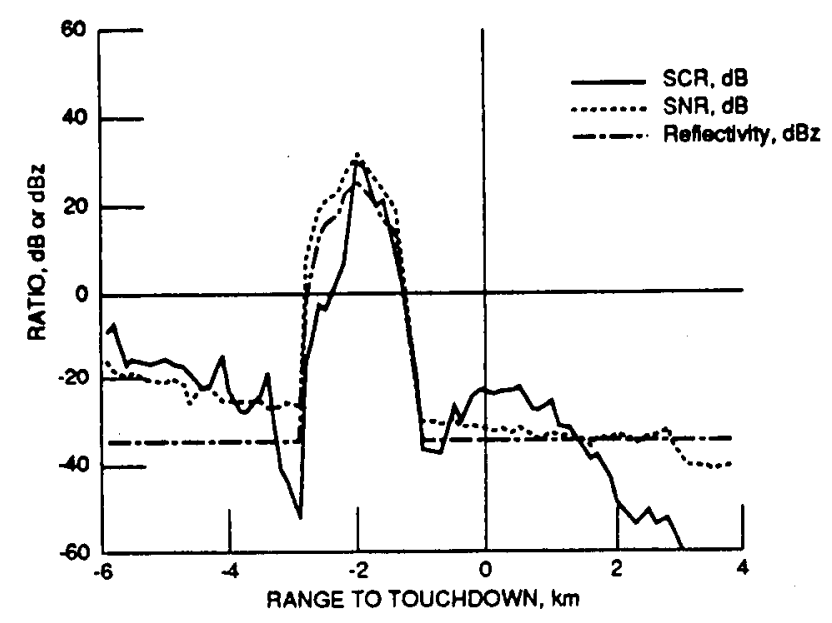

F1g. 16 Plot of calculated SNR, SCR and reflect1vity factor vs range to touchdown for the "dry" microbụst, and conditions listed in f18. 11, except freq. $=15 \mathrm{GHz}$.

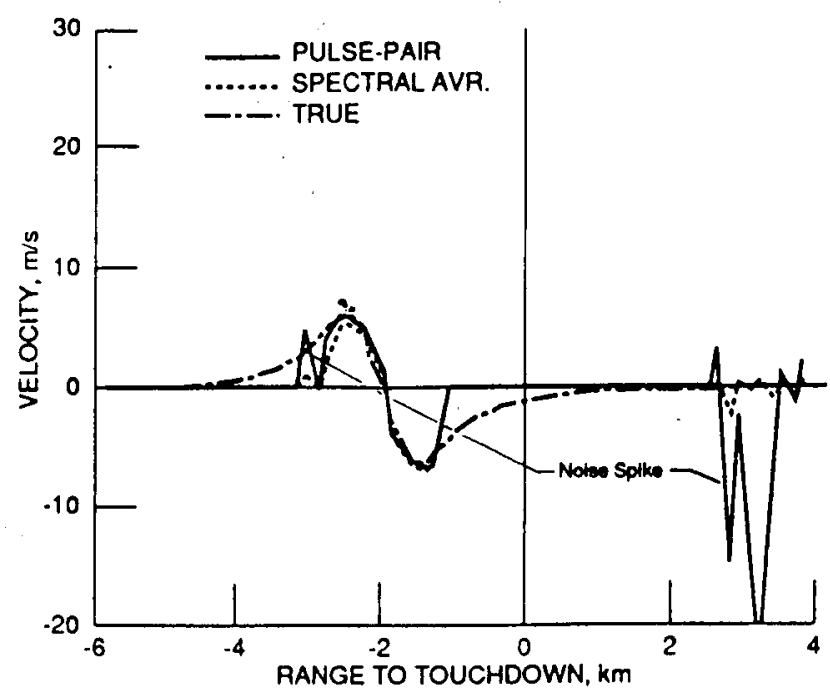

Fig. 17 Radar wind velocity measurement vs range to touchdown under same conditions as those of flgure 16. The noise spikes are due to low $S C R$ from urban clutter ( $-3 \mathrm{~km})$, and other clutter sources $(+3 \mathrm{~km})$ where reflectivity levels are low.

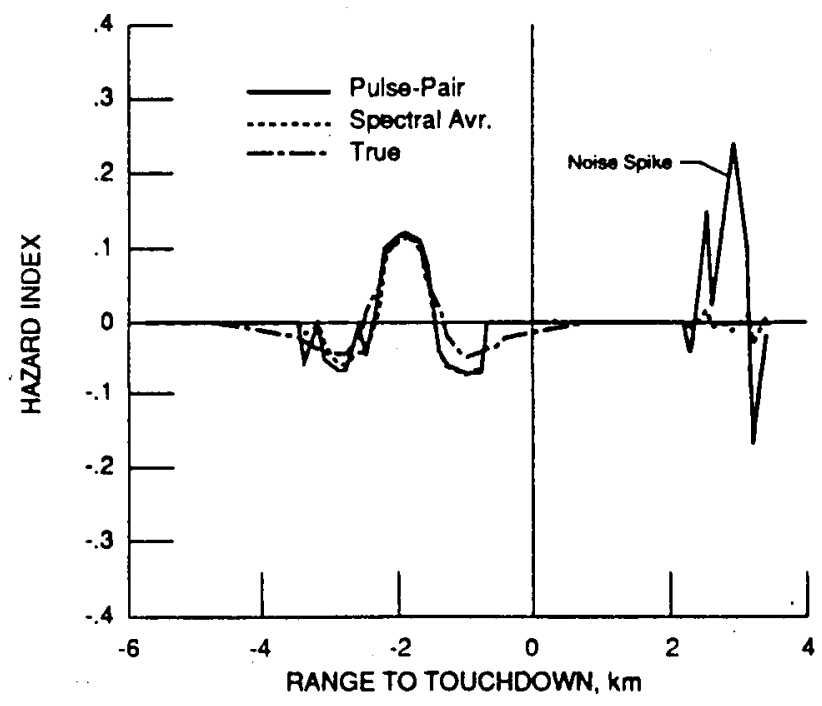

F1g. 18 hazard index vs. range to touchdown derived from the "dry" microburst velocitles shown in figure 17. 


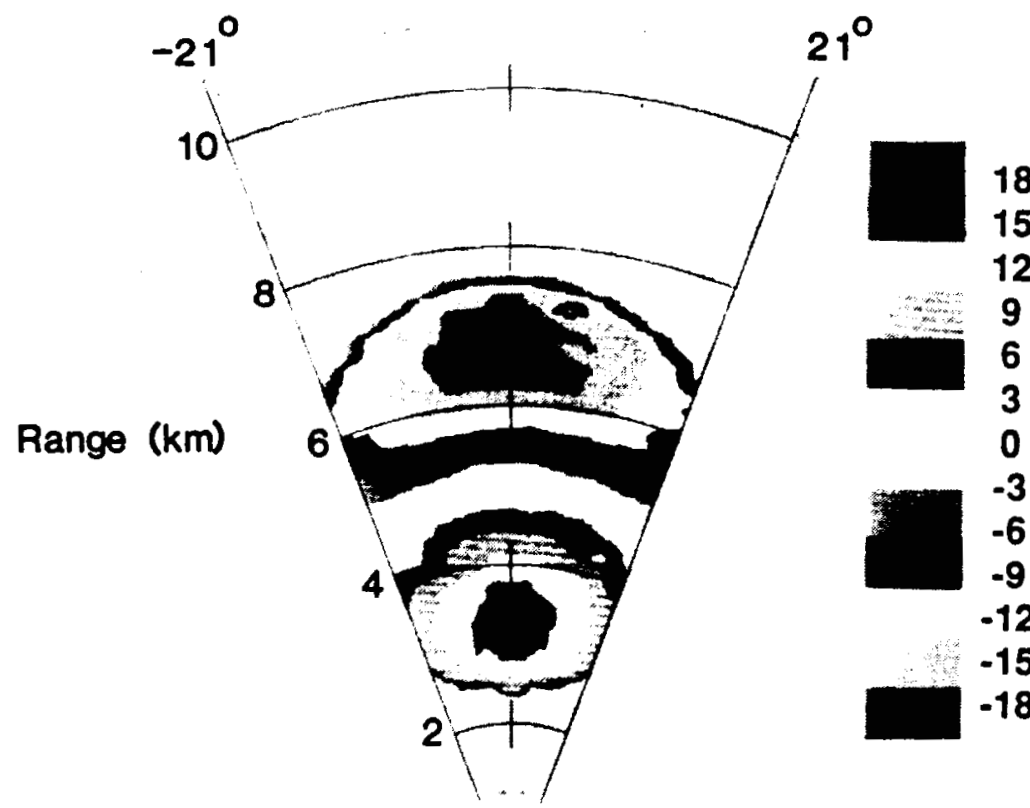

FIg. 19 Range-azimuth dispiay of wind velocity con-

tours for the "wet" microburst, baseline radar parameters, and conditions listed in

f18. 11. The large head to tall velocity and wind direction change is clearly shown.

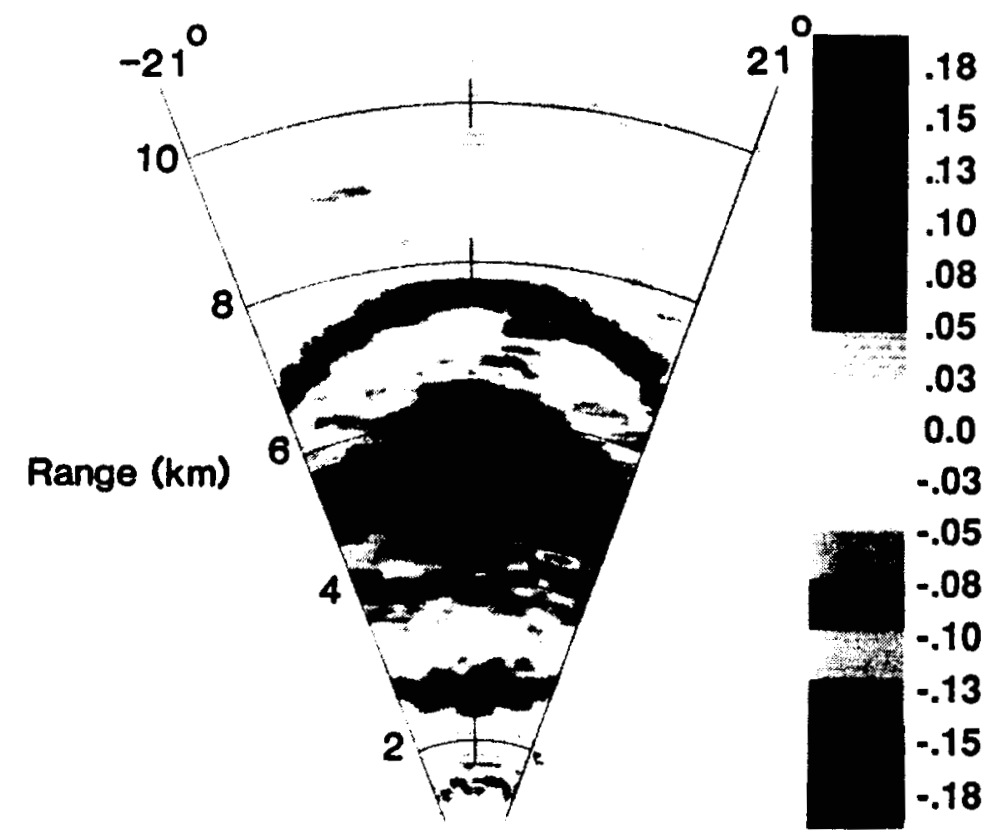

P1g. 20 Range-azimuth display of hazard Index (F-factor) contours for the "wet" microburst, same conditions as f1g. 19. The potentlal shear hazard area is clearly shown. 